Sharif University of Technology
Scientia Iranica
SCIENTIA
I RAN ICA
http://scientiairanica.sharif.edu

\title{
Seismic behavior of chevron concentrically braced frames with weak beams
}

\author{
S.M. Dehghan*, M.A. Najafgholipour, and H. Hooshangi \\ Faculty of Civil and Environmental Engineering, Shiraz University of Technology, Shiraz, P.O. Box 71557-13876, Iran. \\ Received 4 March 2017; received in revised form 21 January 2018; accepted 14 May 2018
}

\author{
KEYWORDS \\ Chevron braced \\ frame; \\ Finite element \\ method; \\ Nonlinear analysis; \\ Response history \\ analysis; \\ Seismic behavior; \\ Weak beam.
}

\begin{abstract}
Concentrically braced frames provide ductility and imparted seismic energy dissipation through yielding of tension braces and buckling of compression braces. In braced frames with chevron configuration, difference of actions in tension and buckled brace results in considerable unbalanced force at brace-beam intersection, which is addressed in modern seismic design provisions. In this paper, the role of flexural capacity of beam in carrying this unbalanced force and consequently, seismic behavior of braced frame were investigated by finite element analysis. Two-story and four-story chevron braced frames were modeled in ABAQUS software and studied by means of nonlinear cyclic pushover and nonlinear response history analysis methods. Results showed that inadequate flexural strength of the beams reduced lateral stiffness and strength of braced frame significantly as lateral drift increased. Therefore, concentration of lateral deformation on one story might cause formation of soft and weak story. Furthermore, seismic behaviors of chevron braced frame and two-story $X$ braced frames were compared.
\end{abstract}

(C) 2020 Sharif University of Technology. All rights reserved.

\section{Introduction}

Lateral force resistance can be provided by different structural systems. Steel Concentrically Braced Frame $(\mathrm{CBF})$ is a lateral force resisting system which serves as a vertical truss for lateral loads such as earthquake and wind. Since in CBF, centerline of brace passes through intersection of beam and column centerline, initially lateral loads are mainly supported by axial tension or compression forces in members. The CBF is a common Seismic Force Resisting System (SFRS) with high lateral stiffness, ease of construction, and low fabrication cost. Many buildings with CBF system are located in high seismic risk regions, such as many

*. Corresponding author. Tel.: +98 7137277656 E-mail addresses: smdehghan@sutech.ac.ir (S.M. Dehghan); najafgholipour@sutech.ac.ir (M.A. Najafgholipour).

doi: $10.24200 /$ sci. 2018.20494 highly populated cities of Iran, e.g. Tehran, Shiraz, Tabriz, and Mashhad.

In the linear behavior range, seismic force is resisted through truss action, while in the nonlinear behavior stage, earthquake energy is dissipated by yielding of tension braces and buckling of compression braces. Therefore, to provide sufficient ductility, braces act as fuses in the CBFs where columns, beams, and connections should remain elastic. Different patterns of bracing, including $\mathrm{X}, \mathrm{V}$, and two-story $\mathrm{X}$, can be employed for the CBFs. For providing architectural access, such as doors and windows, chevron braces with $\mathrm{V}$ and inverted- $\mathrm{V}$ configurations are frequently utilized. As shown in Figure 1, when tension brace yields and compression brace buckles, connecting beam of the $\mathrm{V}$ and inverted-V bracing undergoes large vertical and horizontal unbalanced forces in the nonlinear range, which is not captured in the conventional linear analysis. If the beam does not have sufficient strength to support this unbalanced force, its nonlinear behavior 


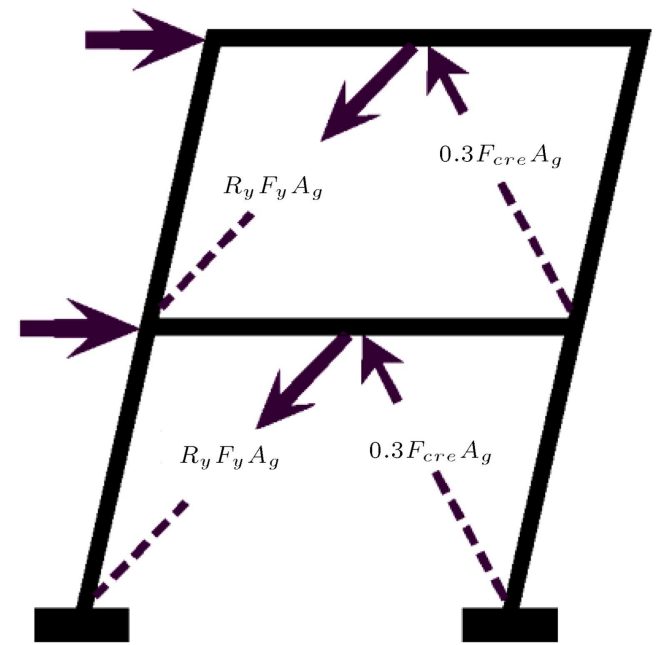

Figure 1. Unbalanced force in the connecting beam of inverted-V SCBF.

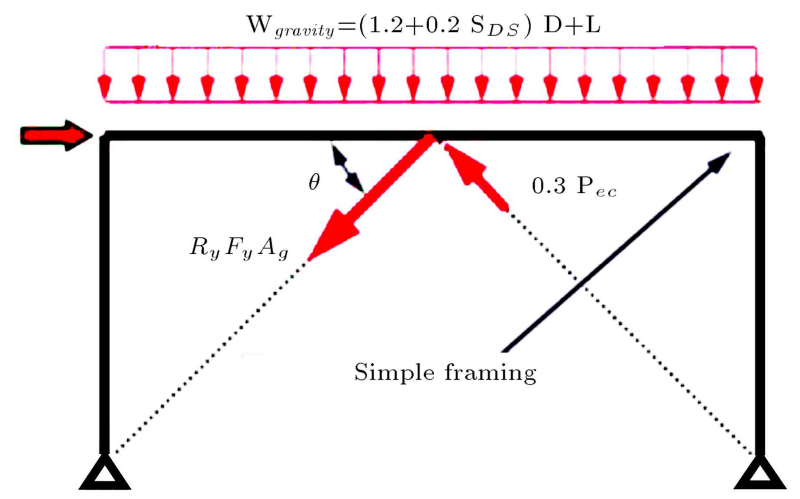

Figure 2. Computing unbalanced force in the inverted-V SCBF as per AISC 341-10.

may alter seismic performance of the chevron CBF system.

Seismic design provisions of chevron CBF [1,2] prescribe that the beam in $\mathrm{V}$ or inverted-V CBF should have sufficient strength to support the unbalanced force and gravity loads as shown in Figure 2. The unbalanced force for Special Concentrically Braced Frame (SCBF) can be computed according to Figure 2 as the difference between the expected brace strength in tension $\left(P_{e t}\right)$ and expected compression strength $\left(P_{e c}\right)$ or expected post buckling strength $\left(=0.3 P_{e c}\right)$. It should be noted that the most critical case of this capacity design procedure should be considered for the beam design.

The expected brace strengths in tension and compression are determined by means of Eqs. (1) and (2):

$$
\begin{aligned}
& P_{e t}=R_{y} F_{y} A_{g}, \\
& P_{e c}=1.14 F_{c r e} A_{g},
\end{aligned}
$$

where $R_{y}, F_{y}, A_{g}$, and $F_{c r e}$ are respectively ratio of the expected yield stress to the specified minimum yield stress of steel, specified minimum yield stress of steel, brace gross area, and expected critical stress in compression (using $R_{y} F_{y}$ instead of $F_{y}$ to compute $F_{c r}$ for flexural buckling).

In this study, the role of beam flexural strength in seismic behavior of two-story and four-story inverted$V$ SCBF systems is investigated through nonlinear cyclic pushover analysis and nonlinear response history analysis. Three types of beam are considered, namely strong beam, weak beam, and very weak beam. Strong beam has sufficient strength following seismic design provisions, while flexural strength of weak and very weak beams is insufficient for supporting the unbalanced force of the braces. Effect of beam flexural capacity on seismic performance is evaluated through story stiffness, story lateral strength, beam vertical deformation, and inter-story drift ratio. Furthermore, influence of bracing configuration (two-story $\mathrm{X}$ versus inverted-V) is investigated to mitigate the adverse effect of weak beam.

Several analytical and experimental investigations have been conducted into lateral behavior and seismic performance of chevron braced frames. The analytical studies are outlined as follows. Different design approaches to multi-story chevron brace were examined by Robert and Tremblay [3] and height limitations were proposed for each design procedure. In addition, a detailed study of a building with chevron brace, which suffered major damage in 1994 Northridge earthquake, was performed by means of response spectrum, nonlinear static (pushover), and nonlinear response history analysis methods [4]. Another analytical study focused on evaluating seismic behavior of conventional $\mathrm{CBF}$ and modeling special CBF [5]. In an analytical study, Kim and Choi [6] assessed over-strength, ductility, and response modification factor of special $\mathrm{CBF}$ and ordinary CBF frame with various numbers of story and span length through pushover and nonlinear incremental dynamic analysis. Furthermore, design of chevron braced frame according to Eurocode was evaluated and a new method was proposed to estimate strength of chevron brace, which was employed for enhanced design of chevron CBF [7]. Dicleli and Mehta [8] compared seismic performances of chevron braced frame with and without damper subjected to near-fault ground motion by nonlinear response history analysis. They also developed a nonlinear structural model to simulate hysteretic load deflection of steel box brace in ADINA software, which was applied to evaluating the structural performance of singlestory chevron braces [9]. Low-ductility chevron braced frames were also studied by incremented dynamic analysis method [10]. Giugliano et al. [11] evaluated seismic performance and reliability of CBFs designed according to traditional and innovative design strategies. Some other researchers investigated overall behavior and 
over-strength factor of a chevron brace with weak beam under lateral loads $[12,13]$. An improved model was developed and validated using a large number of tests by Hsiao et al. [14], which was applied in accordance with FEMA P695 methodology to evaluate seismic performance of different braced frames [15]. Lai and Mahin [16] sought to modify yielding beams in braced frames using a strong-back system and to promote uniform story drift over the height of structure. D'Aniello et al. [17] investigated the influence of beam flexural stiffness on the seismic response of chevron CBFs and showed that besides strength, it had a key role in assuring ductile behavior of CBF. Furthermore, Asghari and Azimi [18] studied ductility reduction factor and response modification factor of CBFs with different story numbers and bracing types including chevron bracing. In a comprehensive study, Kazemzadeh Azad et al. [19] evaluated the design philosophies and provisions used in the AISC 341 and EC8 for CBF systems with different configurations in detail. They concluded that AISC 341 provisions would lead to relatively stronger and stiffer beams in CBF than EC8 requirements would.

Major findings of experimental studies on chevron CBF are summarized here. Fukuta et al. [20] conducted a test on half-scale three-story inverted- $V$ braced frames. They concluded that post-buckling behavior of the brace and the interaction between the brace and the beam mainly affected the total seismic behavior of the frame. In another experimental study, Bubela et al. [21] examined incorporating vertical slotted connection in steel chevron braced frame to prevent vertical load transfer to beam through full-scale quasistatic cyclic tests on two specimens. Dynamic response of steel CBF with chevron arrangement and elliptical fold line in gusset plate connection was investigated through a test on large-scale shaking table [22]. In this study, excellent behavior of connection was observed and yielding in the middle of the beam did occur as predicted in monotonic analysis. However, non-seismic CBFs with low flexural strength beam in chevron configuration were examined by Sen et al. [23-25]. Fullscale two-story braced frame with weak beam tested in this research is employed for verification of the numerical simulation in this study.

\section{Numerical model and verification}

In this section, details of the full-scale test on two-story chevron braced frame with weak beam are presented. The test is used for verification of the numerical simulation as well as the procedure of the analytical model.

\subsection{Details of the tested chevron CBF}

Sen et al. in 2013 conducted tests on two full-scale two-story concentrically inverted- $\mathrm{V}$ chevron braces in National Research Center of Taiwan [23-25]. Both specimens with low ductility detail were categorized as ordinary CBF based on seismic provisions of AISC 34110 [1]. As shown in Figure 3, frames had weak beam in the first story and strong beam in the second story with regard to the unbalanced force of the braces.

In one frame (Figure 3(a)), brace gusset plate without fold line restricted free rotation of the brace to gusset connection, while in the other frame (Figure $3(\mathrm{~b})$ ), the fold line provided proper detail. Both frames had similar sections. Upper slab with thickness of $200 \mathrm{~mm}$ had composite action with steel beam, but lower slab with thickness of $150 \mathrm{~mm}$ was connected to the beam only in few points. Cyclic loading with predefined lateral displacement as plotted in Figure 4 was applied to the upper level by three $980 \mathrm{kN}$ capacity actuators. Figure 5 shows photos of the test frame and post-buckling condition of the compression brace.

\subsection{Numerical modeling procedure}

For verification of the numerical modeling, the twostory frame in Figure 3(b) was simulated by ABAQUS software and numerical results were compared with the test results. Since the aim of this study was evaluating the effect of flexural strength of connecting beam on chevron $\mathrm{CBF}$, influence of brace gusset plate detail was not further studied. For numerical simulation of steel braced frame response, ABAQUS v.6.142 finite element software was employed. Nonlinear behavior of steel material was considered through elastoplastic stress-strain relationship with isotropic strain-hardening effect, as depicted in Figure 6. Yield and ultimate strengths of steel were reported $300 \mathrm{MPa}$ and $400 \mathrm{MPa}$, respectively. Strain-hardening stiffness was $3 \%$ the initial stiffness of $E=200 \mathrm{GPa}$. All of the beams, columns, bracings, and connections were modeled by means of linear quadrilateral shell elements at mid-section of the plate. For buckling and postbuckling behaviors of the bracing, as shown in Figure 7 , the initial imperfection corresponding to buckling mode of the brace with mid-span out-of-crookedness of $1 / 1000$ the brace length was used. To simplify modeling, effect of concrete slab was ignored. Figure 8 presents geometry of the chevron braced frame model including mid-beam and corner gusset plate. The twostory CBF model contains 4075 nodes and 3850 linear quadrilateral and linear triangular shell elements.

\subsection{Comparing test and model results}

The deformed shape of the simulated two-story test frame is presented in Figure 9. Figure 10 compares results of the test and numerical models in ABAQUS, showing that the numerical simulation results adequately comply with the experimental results.

Table 1 lists the relative errors in the test and 


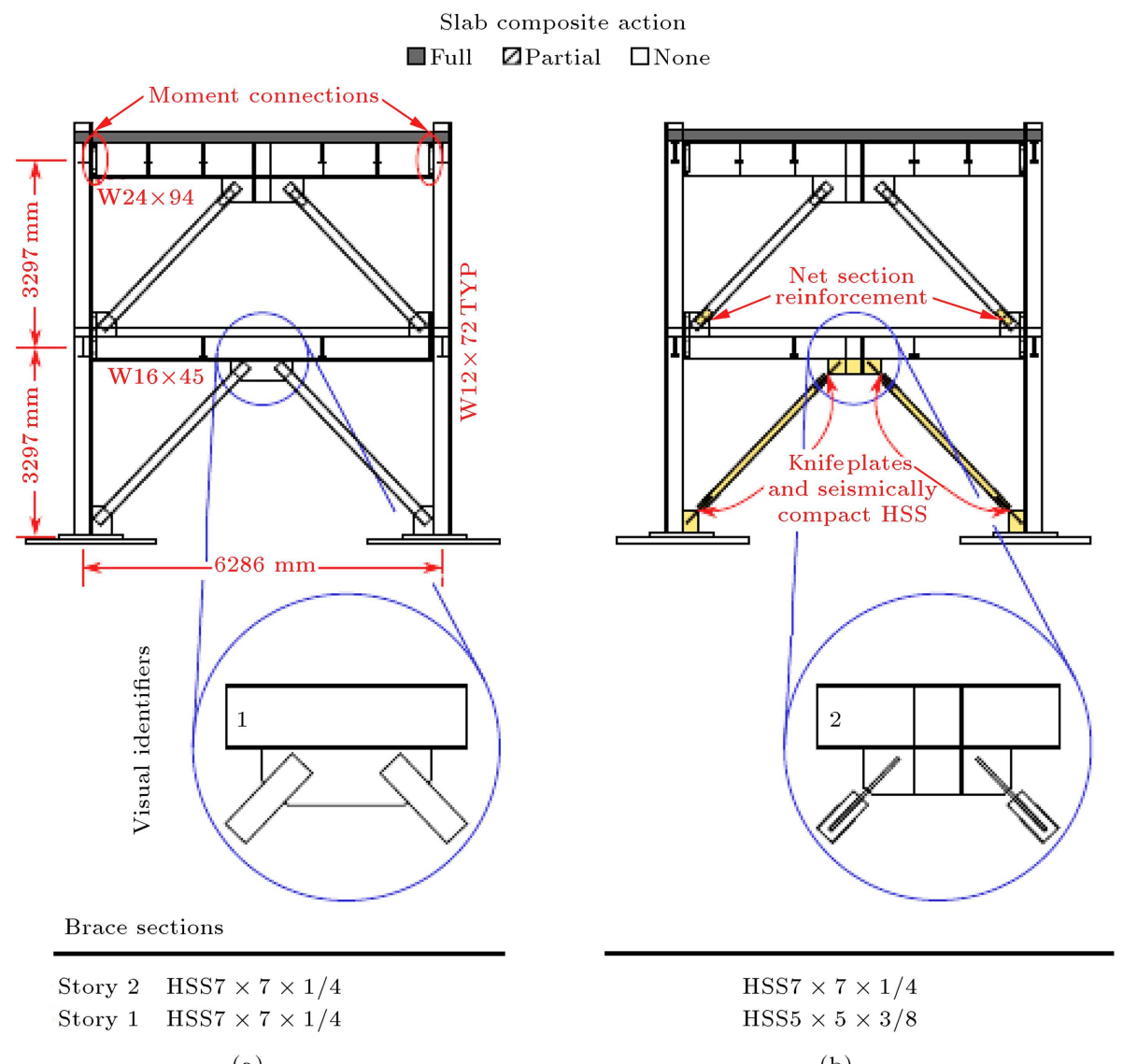

(a)

(b)

Figure 3. Two-story CBF with inverted-V brace with weak beam in the first story: (a) Without fold-line detail and (b) with fold-line detail [25].

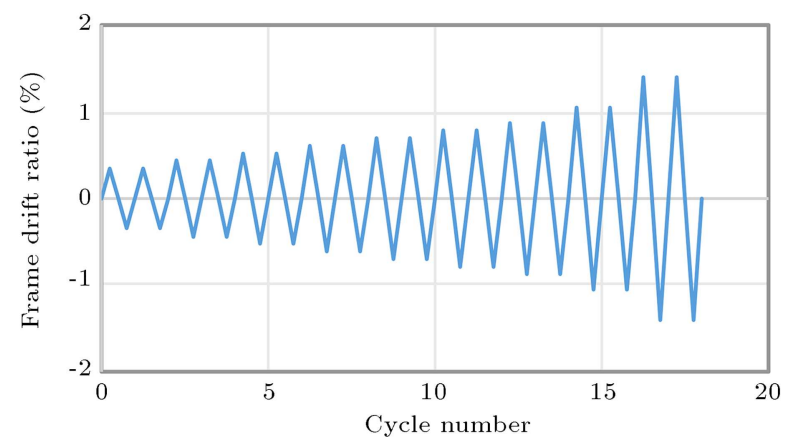

Figure 4. History of the frame drift ratio in the cyclic load test program.

model results for the maximum base shear at different ratios. It is clear that the numerical model can predict lateral load carrying behavior of the chevron CBF with weak beam in the first story. Thus, in the current study, similar simulating approach was employed for further investigation into the seismic behavior of this system.

\section{Model details}

For evaluating weak beam effect on seismic behavior

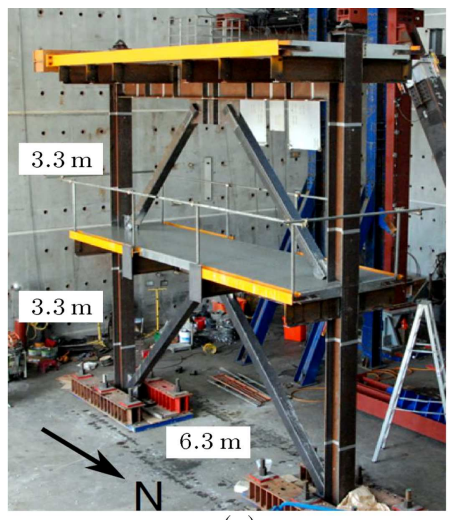

(a)

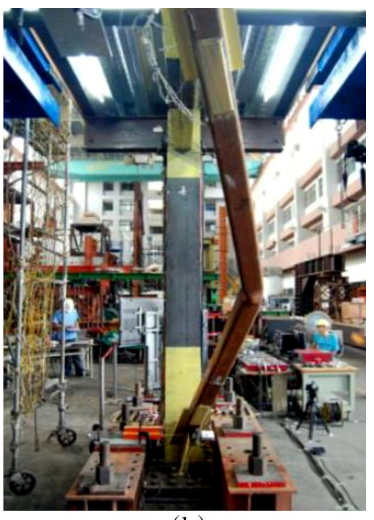

(b)
Figure 5. Two-story $\mathrm{CBF}$ with inverted-V brace with weak beam in the first story: (a) View of the test frame and (b) buckled compression brace [25].

of the CBF with inverted- $\mathrm{V}$ bracing configuration, the two-story and four-story frames presented in Figure 11 were studied. Analytical evaluation was performed through nonlinear cyclic pushover analysis and nonlinear response history analysis procedures.

\subsection{Model building}

Figure 11 shows the typical symmetric square plan 


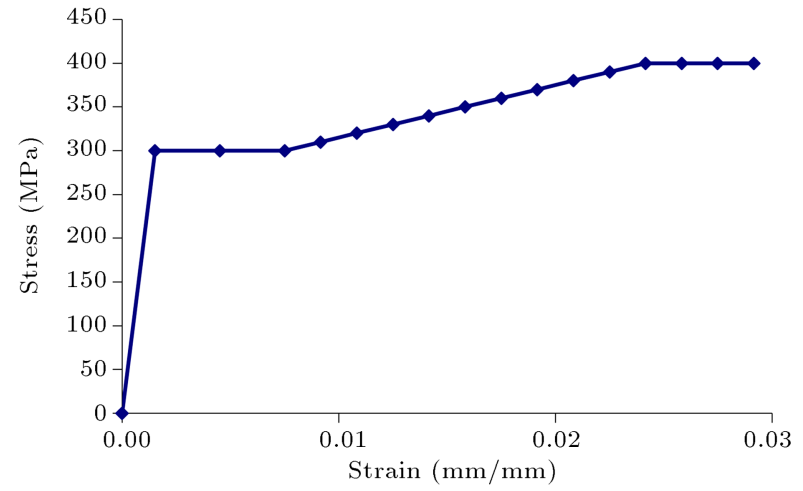

Figure 6. Stress-strain behavior of steel material.

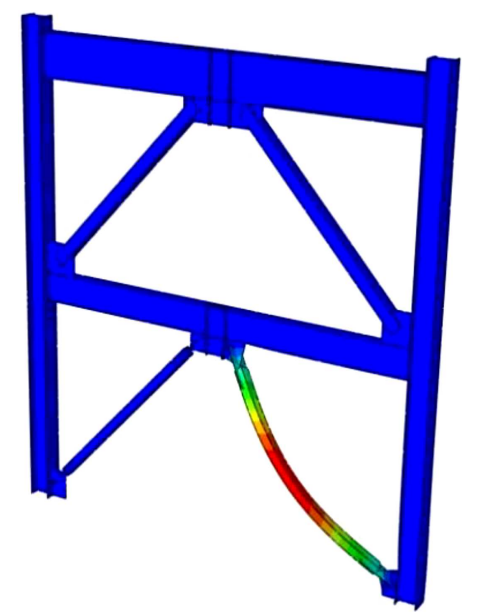

Figure 7. Initial imperfection of bracing with regard to its buckling mode with magnification factor of 5 .

of the model office building with two braced frames on each perimeter axis in both directions. Two- and four-story braced frames with equal heights of 3.2 $\mathrm{m}$ were designed according to AISC 360-10 [26] and AISC 341-10 [1] provisions as Special Concentrically Braced Frames (SCBF). The typical beam, column, and brace sections are tabulated in Table 2. Uniform dead load and live load were considered as $5 \mathrm{kN} / \mathrm{m}^{2}$ and $2.5 \mathrm{kN} / \mathrm{m}^{2}$, respectively. Material properties in
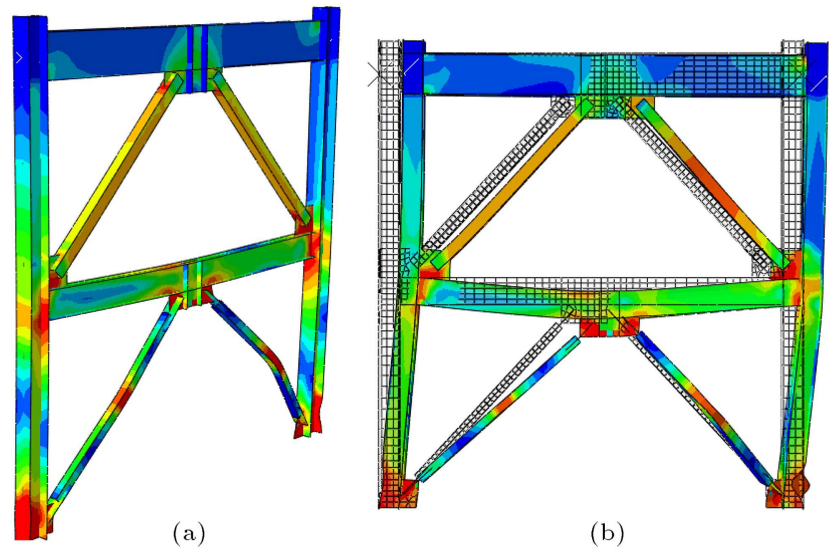

(b)

Figure 9. Simulated two-story CBF inverted-V chevron brace with weak beam in the first story: (a) Out-of-plane buckling of the first-story brace and (b) deformed shape.

Table 1. Relative errors in the test and model results for the maximum base shear at different drifts.

\begin{tabular}{|c|c|c|c|}
\hline \multirow{2}{*}{$\begin{array}{c}\text { Frame drift } \\
\text { ratio }(\%)\end{array}$} & \multicolumn{2}{|c|}{ Base shear (kN) } & \multirow[b]{2}{*}{ Error (\%) } \\
\hline & Test & Model & \\
\hline 0.8 & 1759 & 1602 & 9 \\
\hline 0.9 & 1780 & 1634 & 8 \\
\hline 1 & 1811 & 1655 & 9 \\
\hline 1.3 & 1822 & 1650 & 9 \\
\hline First story & \multicolumn{2}{|c|}{ Base shear $(\mathrm{kN})$} & \\
\hline drift ratio $(\%)$ & Test & Model & Error (\%) \\
\hline 1.2 & 1745 & 1613 & 8 \\
\hline 1.4 & 1767 & 1635 & 7 \\
\hline 1.7 & 1801 & 1669 & 7 \\
\hline 2.1 & 1812 & 1657 & 9 \\
\hline
\end{tabular}

model building were similar to those of the tested braced frames in Section 2.2. The brace sections were chosen to meet strength and drift requirements of the SFRS. The column sections were also selected to satisfy capacity design requirements of AISC 341-10. The Demand Capacity Ratios (DCRs) of beam sections for

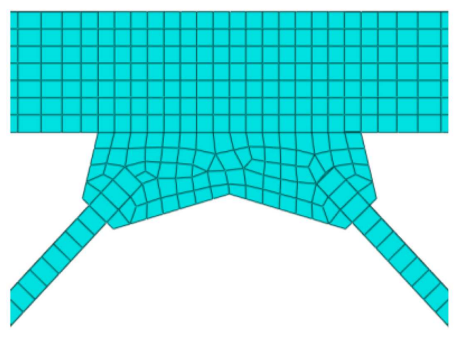

(a)

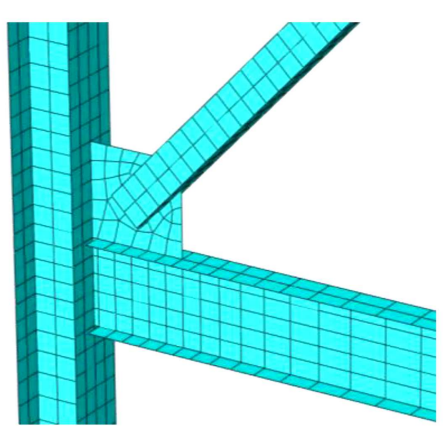

(b)

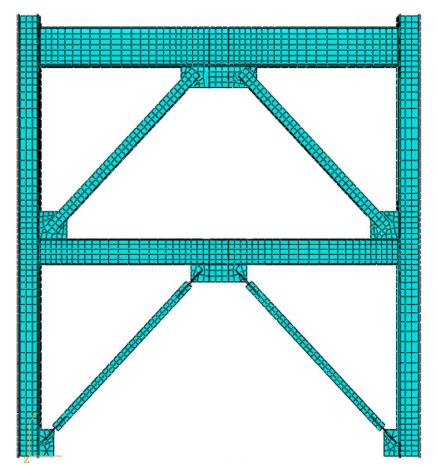

(c)

Figure 8. Geometry of finite element model of the test frame: (a) Mid-beam gusset plate, (b) corner gusset plate, and (c) $3 \mathrm{D}$ view. 


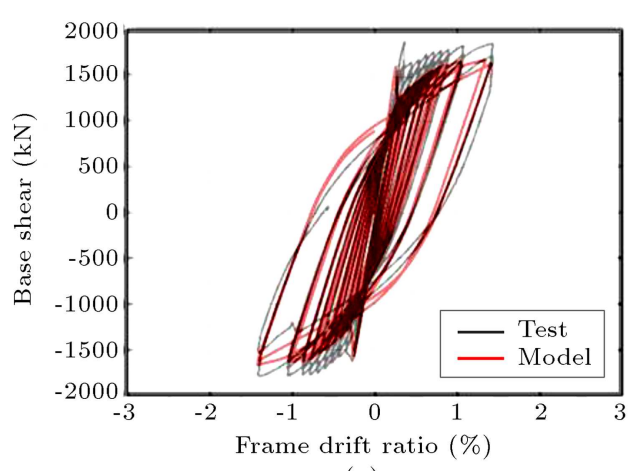

(a)

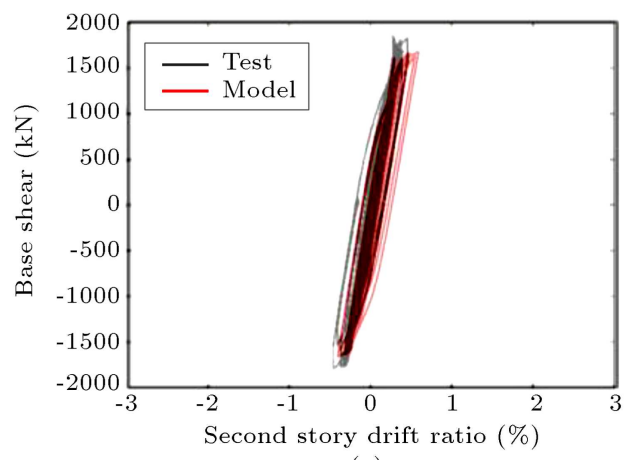

(c)

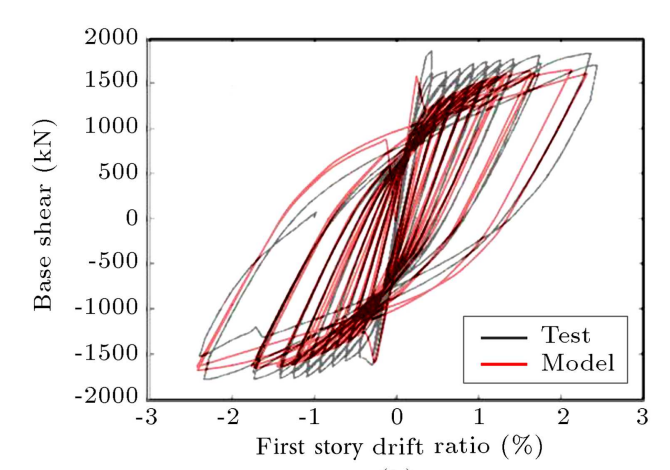

(b)

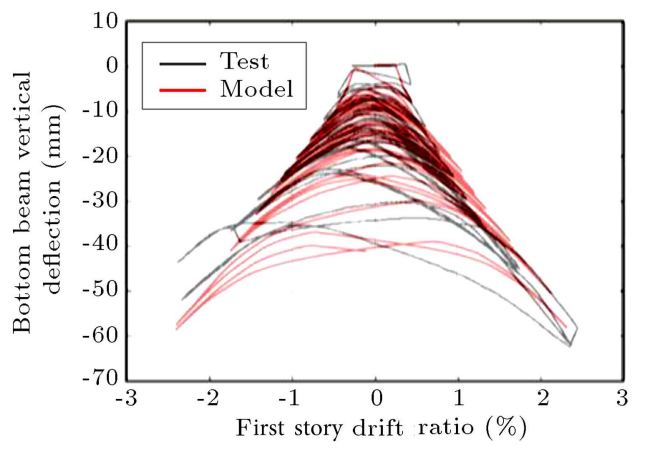

(d)

Figure 10. Comparison between the experiment results [23-25] and numerical simulation results in ABAQUS: (a) Base shear-frame drift, (b) shear drift of the first story, (c) shear drift of the second story, and (d) vertical displacement of the beam drift of the first story.

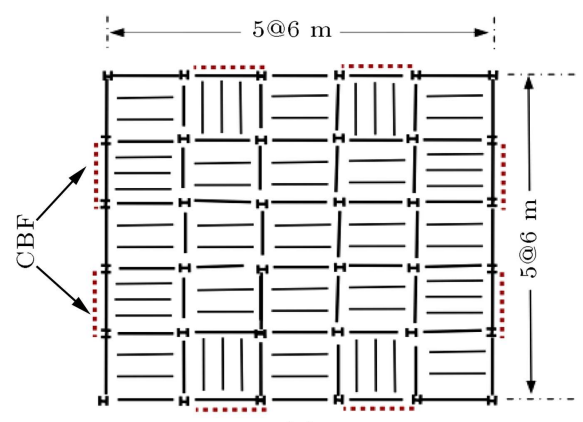

(a)

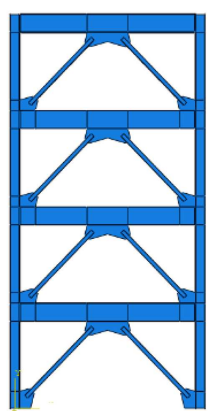

(b)

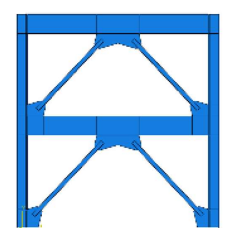

(c)

Figure 11. Details of model building: (a) Typical plan, (b) elevation of two-story chevron CBF, and (c) four-story chevron CBF.

Table 2. Braced frame sections.

\begin{tabular}{|c|c|c|c|c|c|}
\hline Column of two-story CBF & Column of $\mathrm{fc}$ & ir-story CBF & Brace & Beam & Tyne of heam \\
\hline 1st and 2nd & 1st and 2nd & 3rd and 4 th & Bidate & Beani & Нуре бi teant \\
\hline $\mathrm{W} 12 \times 72$ & $\mathrm{~W} 12 \times 87$ & $\mathrm{~W} 12 \times 72$ & $\mathrm{HSS} 5 \times 5 \times 3 / 8$ & $\mathrm{~W} 24 \times 94$ & Strong \\
\hline $\mathrm{W} 12 \times 72$ & $\mathrm{~W} 12 \times 87$ & $\mathrm{~W} 12 \times 72$ & $\mathrm{HSS} 5 \times 5 \times 3 / 8$ & $\mathrm{~W} 16 \times 45$ & Weak \\
\hline $\mathrm{W} 12 \times 72$ & $\mathrm{~W} 12 \times 87$ & $\mathrm{~W} 12 \times 72$ & $\mathrm{HSS} 5 \times 5 \times 3 / 8$ & IPE270 & Very weak \\
\hline
\end{tabular}

supporting the unbalanced force as described in Figure 2 are presented in Table 3. Regarding the DCRs of the beams in Table 3, three types of beam sections were considered, namely strong beam, weak beam, and very weak beam. Since braces and beam sections were similar in all stories, the DCRs of all beams were equal.

\subsection{Selecting and scaling ground motions}

The modeled buildings were considered to be located on Site Class D (Stiff Soil) near Tehran in Imam Khomeini International Airport and the corresponding MCE level spectral response acceleration parameters $\left(S_{S}\right.$ and $\left.S_{1}\right)$ based on ASCE 7-10 requirements [27] were derived 
Table 3. Demand capacity ratios of beam sections according to AISC-341-10 provisions.

\begin{tabular}{|c|c|c|c|c|c|c|c|c|c|}
\hline $\begin{array}{c}\text { Type of } \\
\text { beam }\end{array}$ & $\begin{array}{l}\text { Beam } \\
\text { section }\end{array}$ & $\begin{array}{c}\text { Area, } \\
\qquad \begin{array}{c}A \\
\left(\mathrm{~mm}^{2}\right)\end{array}\end{array}$ & $\begin{array}{c}\text { Plastic } \\
\text { modulus, } \\
Z \\
\left(\times 10^{\mathbf{3}} \mathrm{mm}^{\mathbf{3}}\right) \\
\end{array}$ & $\begin{array}{c}\text { Brace-to-beam } \\
\text { angle } \\
(\text { deg })\end{array}$ & $\begin{array}{c}\text { Unbalanced } \\
\text { shear force } \\
(\mathrm{kN})\end{array}$ & $\begin{array}{l}\text { Unbalanced } \\
\text { axial force } \\
(\mathrm{kN})\end{array}$ & $\begin{array}{c}\text { Span } \\
\text { length } \\
(\mathrm{mm})\end{array}$ & $\begin{array}{c}\mathrm{Mu} \\
(\mathrm{kN} . \mathrm{m})\end{array}$ & DCR \\
\hline Strong & W24x95 & 17,871 & 4,110 & 46.4 & 648 & 1528 & 6,286 & 1,018 & 0.92 \\
\hline Weak & W16x45 & 8,581 & 1,339 & 46.4 & 654 & 1509 & 6,287 & 1,028 & 2.84 \\
\hline Very weak & IPE270 & 4,590 & 484 & 47.4 & 669 & 1469 & 6,288 & 1,052 & 8.05 \\
\hline
\end{tabular}

Table 4. Calculation of design response parameters $\left(S_{D S}\right.$ and $\left.S_{D 1}\right)$ based on ASCE 7-10.

\begin{tabular}{|c|c|}
\hline $\begin{array}{l}\text { Location: Imam Khomeini international airport } \\
35^{\circ} 24^{\prime} 32^{\prime \prime} \mathrm{N} \quad 51^{\circ} 09^{\prime} 17^{\prime \prime} \mathrm{E}\end{array}$ & $\begin{array}{l}\text { 11.4.3 Site coefficients and risk-targeted maximum } \\
\text { considered earthquake (MCER) spectral response }\end{array}$ \\
\hline Soil type: & Acceleration parameters in ASCE standard \\
\hline \multirow{2}{*}{$\mathrm{D}$} & $S_{M S}=F_{a} \cdot S_{S}=2.0440$ \\
\hline & $S_{M 1}=F_{v} \cdot S_{1}=0.9435$ \\
\hline \multirow[t]{2}{*}{ Using Iranhazard.mprog.ir } & 11.4.4 Design spectral acceleration parameters \\
\hline & in ASCE standard \\
\hline$S_{s}=2.044$ & $S_{D S}=2 / 3^{*} S_{M S}=1.3627$ \\
\hline$S_{1}=0.629$ & $S_{D 1}=2 / 3^{*} S_{M 1}=0.6290$ \\
\hline Using Tables 11.4-1 and 11.4-2 in ASCE standard & ASCE standard design spectrum \\
\hline for $S_{s}, S_{1}$, and soil typ & period parameters \\
\hline$F_{a}=1$ & $T_{0}=0.2 S_{D 1} / S_{D S}=0.0923$ \\
\hline$F_{v}=1.5$ & $T_{S}=S_{D 1} / S_{D S}=0.4616$ \\
\hline
\end{tabular}

Table 5. Selected ground motions and scale factors for two-story braced frames.

\begin{tabular}{ccccc}
\hline Category & Tag & Record title & PGA (g) & $\begin{array}{c}\text { Scale factor } \\
\text { (2-story) } \\
\mathbf{T}=\mathbf{0 . 2 3 8 ~ s e c ~}\end{array}$ \\
\hline \multirow{2}{*}{ Near field } & NF-1 & RSN1086_NORTHR_SYL360 (Northridge) & 0.843 & 0.9958 \\
& NF-2 & RSN495_NAHANNI_S1280 (Nahanni) & 1.2007 & 0.6991 \\
\hline \multirow{2}{*}{ Far field } & FF-3 & FRIULI.A-A-TMZ270 (Friuli) & 0.3151 & 2.6639 \\
& FF-4 & RSN174-IMPVALL.H_H-E11230 (ImpVall) & 0.379 & 2.2149 \\
& FF-6 & RSN848-LANDERS_CLW-TR (Landers) & 0.4172 & 2.0121 \\
& FF-7 & RSN1633-MANJIL_ABBAR-T (Manjil) & 0.497 & 1.689 \\
\hline
\end{tabular}

from the database available on IranHazrd Website [28] for the geographical location of the site. The design response spectrum parameters presented in Table 4 were calculated as prescribed in ASCE 7-10.

A suite of seven ground motions, including 2 near-field and 5 far-field records, for the site class and seismic hazard parameters of ASCE 7-10 were selected and scaled for two-story braced-frame buildings to design level earthquake hazard as listed in Table 5. Figure 12 shows response spectrum of scaled ground motions. Average response spectrum of seven records before and after scaling is compared with the design response spectrum in Figure 13.

\section{Results and discussion}

Results of numerical simulation of chevron braced frames by means of ABAQUS software are presented in this section. At the first stage, similar to the experimental study of Sen et al. [23-25], cyclic dis- 


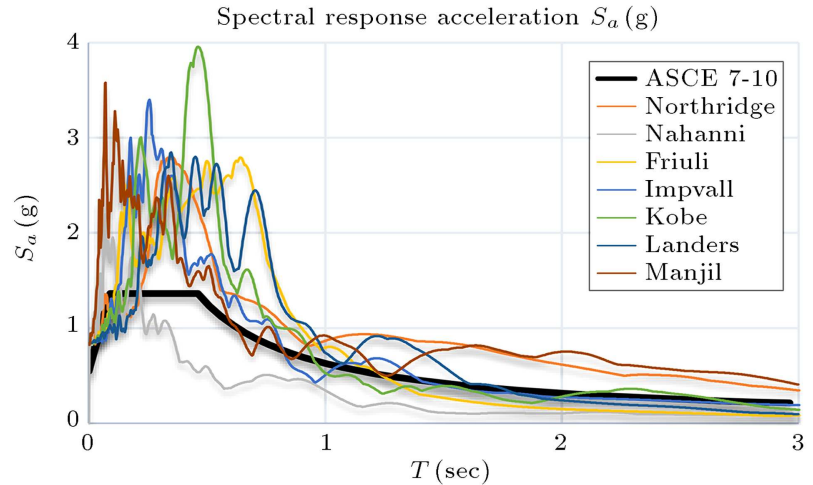

Figure 12. Response spectrum of the scaled ground motions.

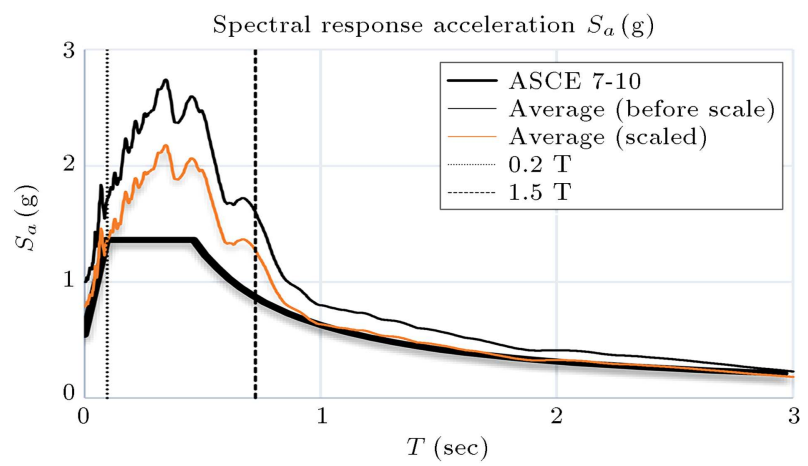

Figure 13. Comparison of average response spectrum of scaled records with design spectrum of ASCE 7-10.

placement control loading of roof level was applied to the numerical model of the braced frames. Two main goals of further investigation into cyclic pushover loading were firstly, to extend results to multi-story, i.e. two- and four-story, braced frames with weak beams in all stories and secondly, to evaluate the effect of very weak beam section, which is commonly encountered in the existing chevron braced frames in Iran. In addition, analytical modeling enables finding different structural performance parameters. At the second stage, response history analysis of two-story model buildings subjected to scaled ground motions was performed to gain insight into seismic performance of chevron braced frames with weak beams posed to design level seismic hazard. Finally, seismic behaviors of two-story $\mathrm{X}$ and chevron four-story braced frames with weak beams were compared.

\subsection{Cyclic pushover analysis of chevron braced frame}

In cyclic pushover analysis, it is observed that, similar to the load history in Figure 4, maximum drift ratio of roof level increases step by step. Figures 14 and 15 show deformed shapes of two-story and four-story frames, respectively. Figures 16 and 17 respectively present responses of two-story and four-story frames in cyclic pushover analysis. In Figures 16 and 17,

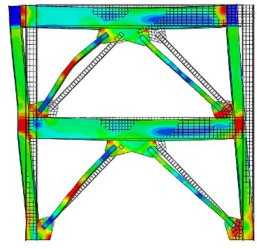

(a)

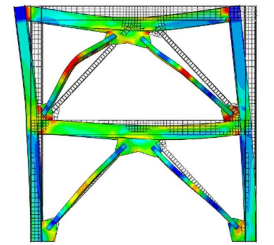

(b)

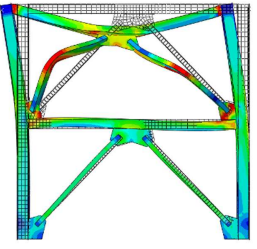

(c)
Figure 14. Deformed shape of two-story chevron braced frame with scale factor of 5: (a) Strong, (b) weak, and (c) very weak.

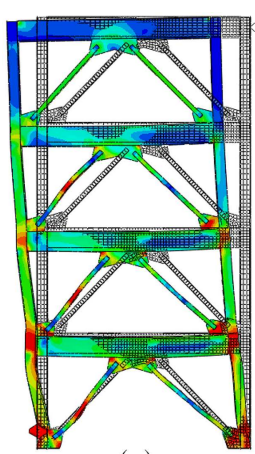

(a)

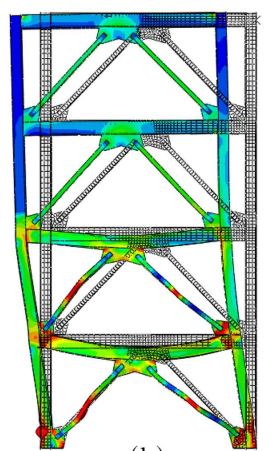

(b)

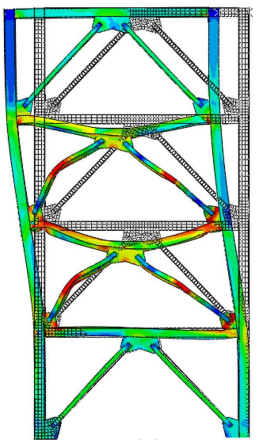

(c)
Figure 15. Deformed shape of the four-story chevron braced frame with scale factor of 5: (a) Strong, (b) weak, and (c) very weak.

base shear is plotted versus story drift. Note that in cyclic pushover analysis, control displacement is only applied to roof level; thus, story shear of each level is equal to base shear. Out-of-plane buckling of braces in chevron braced frames with strong, weak, and very weak beams occurs in deformation at story drifts of $0.35 \%$ to $0.4 \%$, as shown in Figures 14 and 15 . When beam strength is sufficient (Figures 14(a) and $15(\mathrm{a})$ ), vertical deformation of beam is slight. Decreasing beam strength results in considerable increase in vertical deformation of beam (Figures 14(c) and $15(\mathrm{c}))$. High vertical deformation of beam, which is accompanied by buckling of compression brace, causes concentration of lateral displacement in few stories. Therefore, for weak and very weak beam cases, most of the lateral displacement is concentrated on one story, while for the strong beam case, lateral deformation is relatively uniform.

Adequate flexural strength of beam leads to its limited vertical deformation and uniform height-wise lateral displacement distribution following brace buckling. Weak and very weak beams cause loss of lateral stiffness and strength of the braced frame. Initially, all the frames have approximately equal lateral strengths, but the frame strength drops down suddenly as drift increases and consequently, compression braces buckle in weak beam and very weak beam cases. Further increase in lateral drift has small effect on the frame strength. In the case of two-story braced frame, the average 


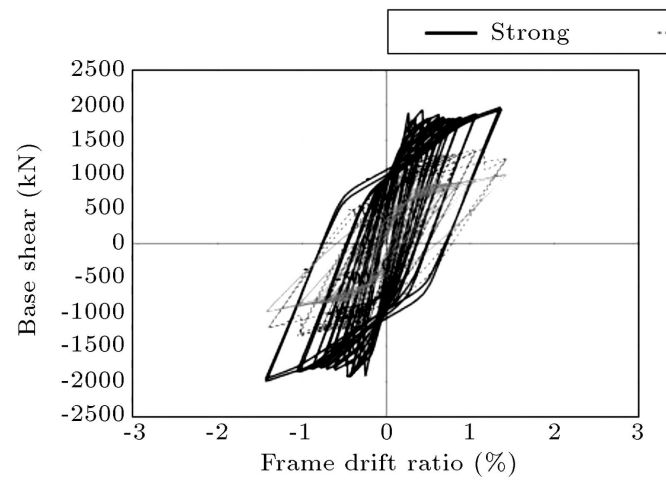

(a)

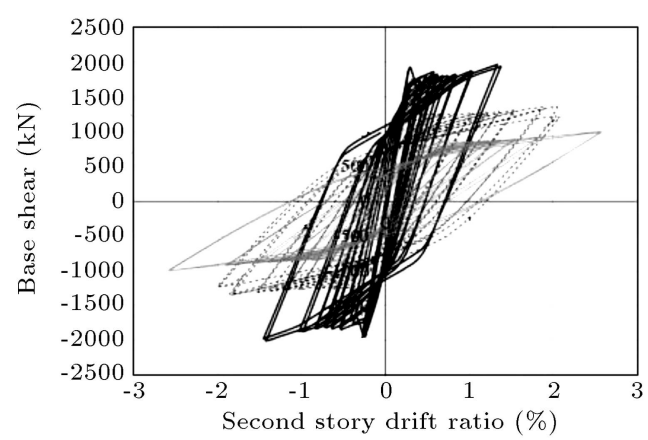

(c)

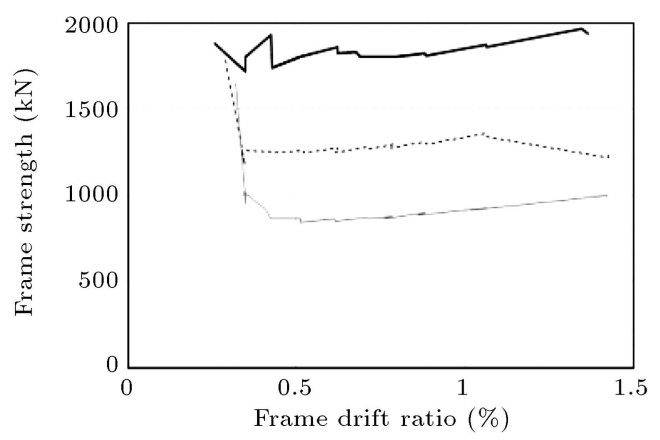

(e)

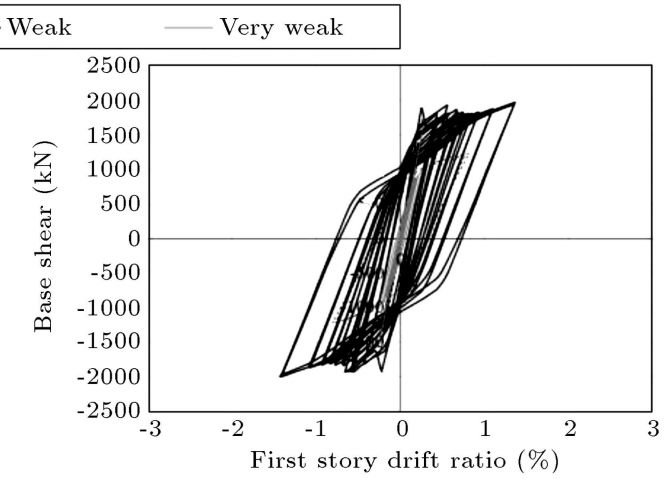

(b)

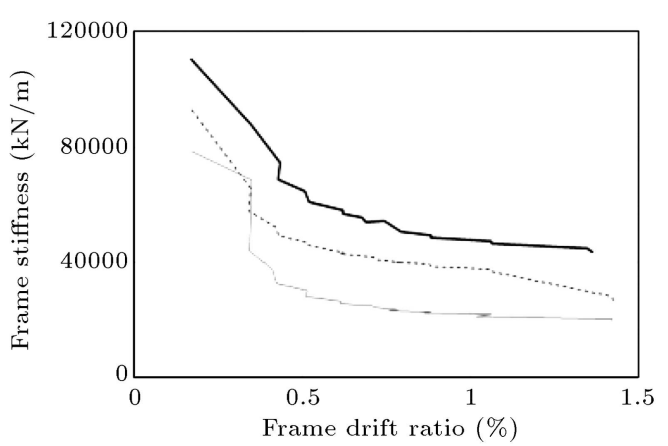

(d)

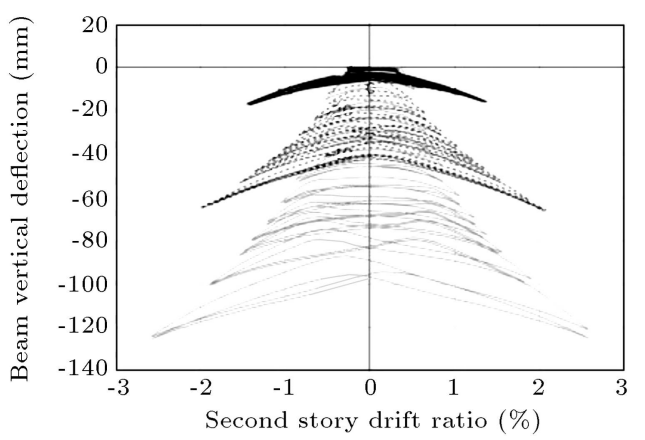

(f)

Figure 16. Comparison of the results for two-story chevron braced frame in cyclic pushover analysis: (a) Shear drift of frame, (b) shear drift of the first story, (c) shear drift of the second story, (d) lateral stiffness drift of frame, (e) lateral strength drift of frame, and (f) vertical deformation drift of the second-story beam.

strengths of frames with weak beams and very weak beams are reduced $31 \%$ and $52 \%$, respectively, with respect to the frame with strong beam. For four-story braced frame, the average strengths of frames with weak and very weak beams decrease $19 \%$ and $42 \%$, respectively, with respect to the frame with strong beam.

The beam strength has direct effect on initial lateral stiffness (elastic stiffness) of the braced frames. The initial relative stiffness of braced frames with weak and very weak beams is respectively $84 \%$ and $71 \%$ for two-story frame and $88 \%$ and $81 \%$ for four-story frame with respect to braced frame with strong beam. The lateral stiffness of all braced frames gradually decreases as lateral drift increases, but lower beam strength causes higher rate of stiffness reduction (in average, $25 \%$ decrease for the weak beam and $50 \%$ decrease for the very weak case with respect to the strong beam). Thus, reduction in lateral stiffness and lateral strength of the chevron braced frames is enhanced with decrease in flexural strength. The combination of lower lateral strength and decrease in lateral stiffness may cause soft or weak story for the frames with weak and very weak beams.

\subsection{Nonlinear response history analysis of two-story chevron braced frames}

Seven ground motions, as presented Table 2, were scaled to code-based design level records, which were used for response history analysis of two-story chevron braced frames. It is worth noting that the mass of 


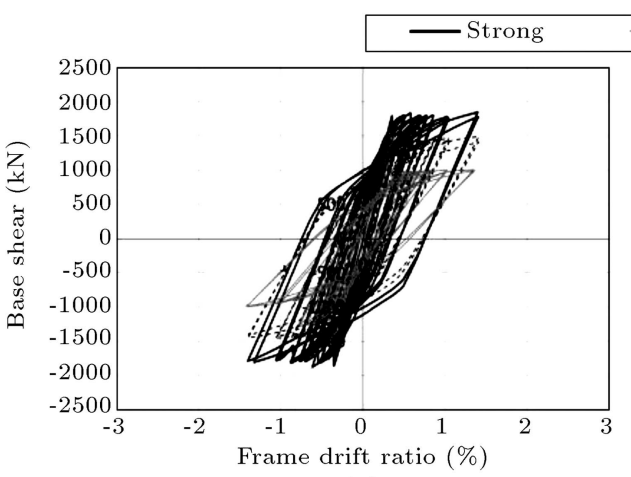

(a)

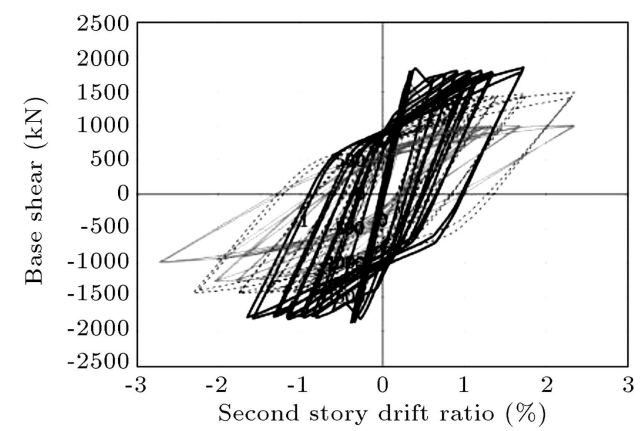

(c)

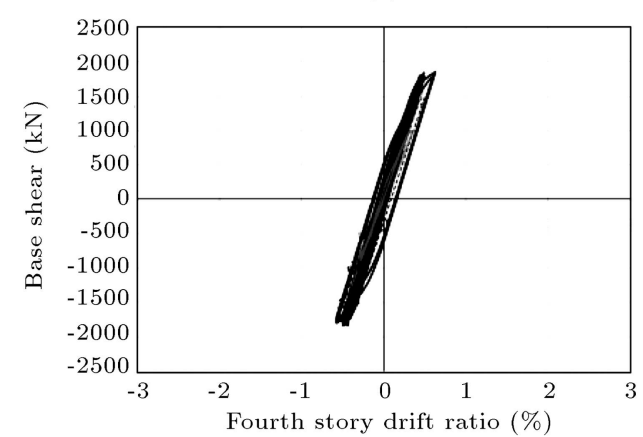

(e)

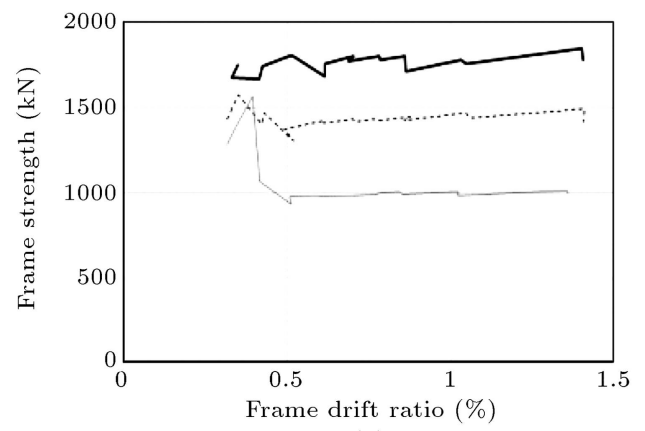

(g)

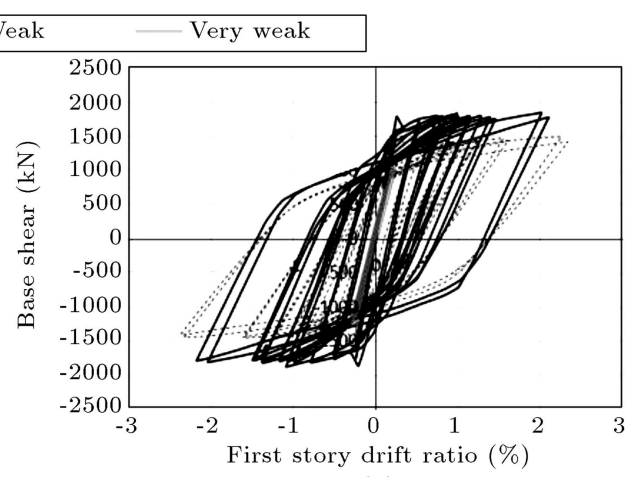

(b)

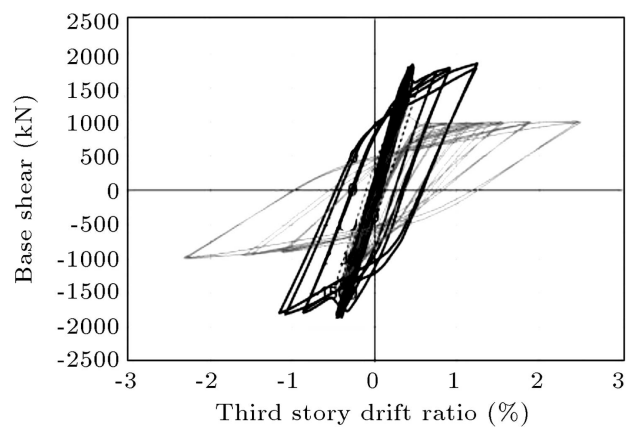

(d)

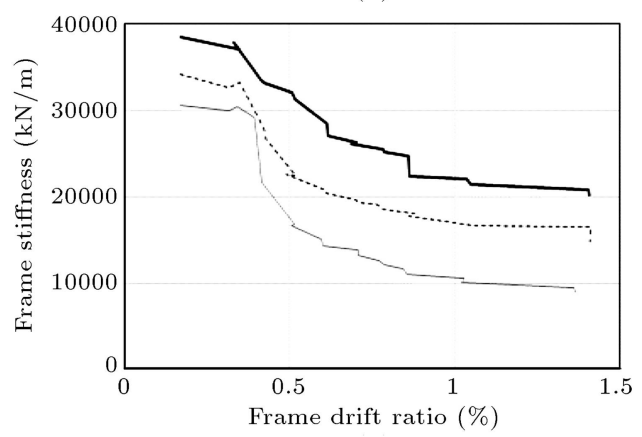

(f)

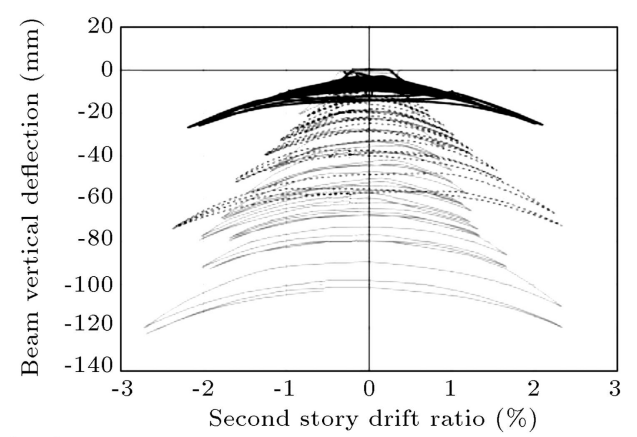

(h)

Figure 17. Comparison of the results for four-story chevron braced frame in cyclic pushover analysis: (a) Shear drift of frame, (b) shear drift of the first story, (c) shear drift of the second story, (d) shear drift of the third story, (e) shear drift of the fourth story, (f) lateral stiffness drift of frame, ( $\mathrm{g}$ ) lateral strength drift of frame, and (h) vertical deformation drift of the second-story beam.

tributary area of each frame (one fourth the plan area in Figure 11) was assigned to each story of the frame, and because the plan was symmetric, only one component of ground motion was applied to the plane of the frame in the numerical simulation.
Figure 18 shows the scaled deformed shape of twostory frames subjected to scaled FF-6 record (Landers) at maximum roof displacement time. In all cases, outof-plane buckling of the braces occurred. For the strong beam (Figure 18(a)), vertical deformation of beam was 


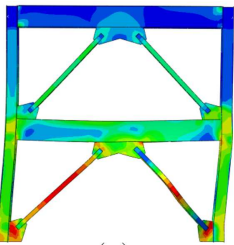

(a)

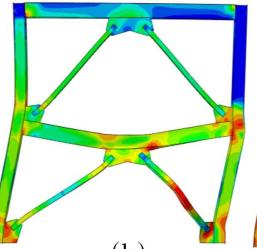

(b)

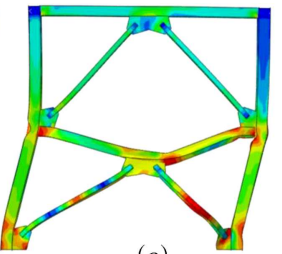

(c)
Figure 18. Deformed shape of the two-story chevron braced frame with scale factor of 4 subjected to FF-6 record at peak roof displacement: (a) Strong, (b) weak, and (c) very weak.

relatively small. As flexural capacity of the beam decreased, vertical deformation considerably increased; thus, like in the cyclic pushover analysis, concentration of lateral displacement in one or two stories was expected. This flexural deformation of beam caused buckling of compression brace and prevented yielding of tension brace, which was not the predefined expected lateral behavior of braced frames. Formation of a soft first story was generally observed.

Effects of beam strength on base shear in comparison with drift of roof and the first story subjected to FF-6 record are presented in Figures 19. When the beam is weak, strength degradation and stiffness reduction lead to brace buckling.

History of mid-span vertical deformation of the first-story beam under FF-6 earthquake is shown in Figure 20. Strong beam results in limited vertical mid-span deflection, which enables yielding of tension brace. In contrast, low strength leads to yielding of the beam and consequently, large beam deflection, which prevents yielding of tension brace after buckling of compression brace. In fact, axial force of tension brace is limited to beam shear load-carrying capacity, which is related to mid-span flexural hinge formation mechanism. For weak and very weak beams, considerable residual vertical deformation could be observed at the end of earthquake.

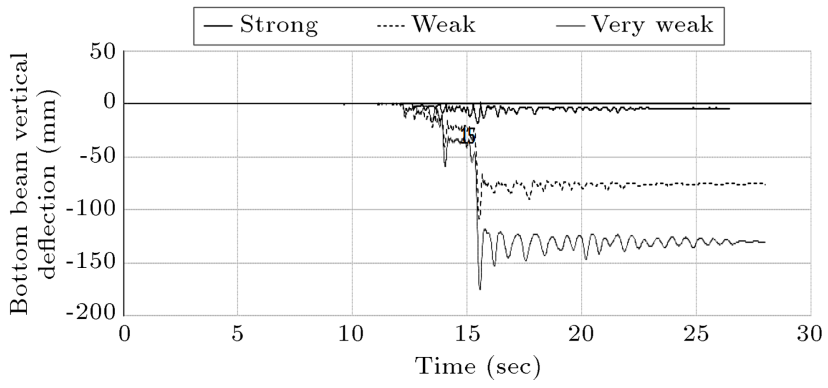

Figure 20. Mid-span vertical deformation history of the first-story beam in two-story braced frame subjected to FF-6 earthquake.

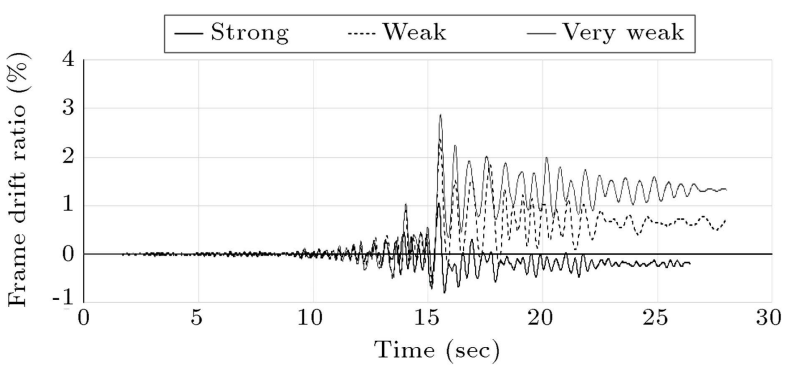

Figure 21. Frame drift history of two-story braced frame subjected to FF-6 earthquake.

History of roof drift subjected to FF-6 earthquake is presented in Figure 21. After buckling of compression brace, frame drift is mostly concentrated in one direction. Generally, low-strength beam results in higher frame drift. Cumulative residual drift of the frame may occur, which is usually higher for braced frame with weak or very weak beam.

Plastic strain of members at peak displacement of the first story is presented in Figure 22. No plastic strain could be observed in strong beams, which verifies elastic behavior of the beam. As expected in the CBF system with adequate beam, the plastic strain in tension brace is related to yielding and plastic strain

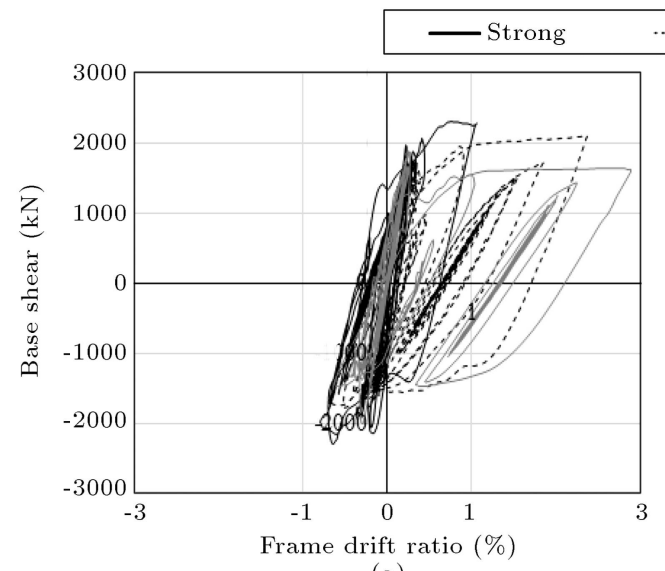

(a)

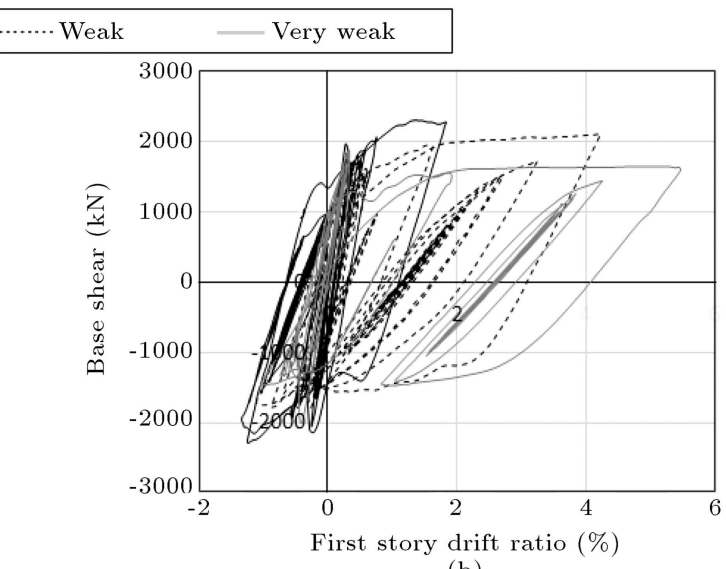

(b)

Figure 19. Response of two-story braced frame under FF-6 record: (a) Base shear drift of frame and (b) base shear drift of the first story. 

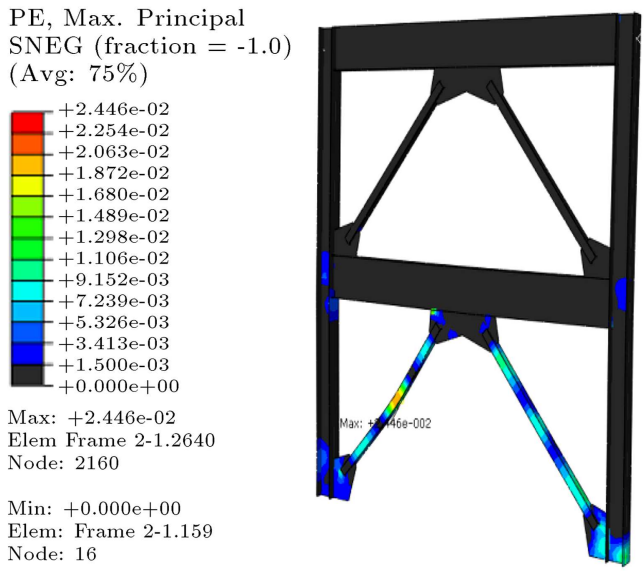

(a)

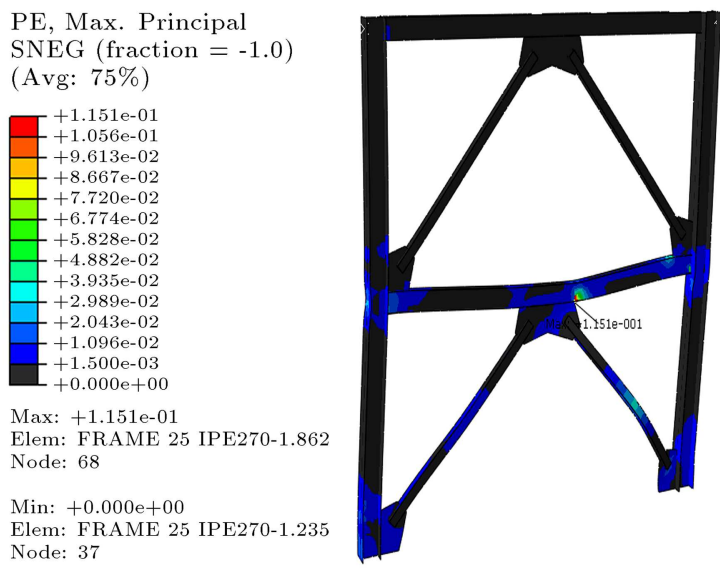

(b)

Figure 22. Plastic strain at peak lateral displacement of the first story in two-story braced frame subjected to FF-6 earthquake: (a) Strong beam and (b) very weak beam.

of compression brace is caused by post-buckling midspan flexural deformation of bracing. However, plastic strain mainly occurs in the beam of the braced frame with very weak beams, which represents plastic hinge formation. Large plastic strain of beam can possibly lead to beam failure, which needs fine modeling to be captured by means of FEM fracture modeling. No plastic strain could be observed in tension braces of frames with very weak beam, but compression braces experience buckling-related plastic strain. Some plastic strain occurs in the columns of the braced frame with very weak beam, which shows that larger shear is resisted by frame action of columns after brace buckling. Lower beam strength results in different loadcarrying mechanism of the braced frame, in which part of lateral load is resisted through frame action instead of truss action.

Table 6 summarizes results of nonlinear response history analysis for all the scaled ground motions. The tabulated results include the maximum base shear, roof displacement, story to frame drift ratio, mid-span vertical displacement of beam, and unbalanced beam force. The unbalanced force is presented in terms of horizontal (axial) and vertical (shear) forces.

Regarding flexural strength of the beam in the braced frame, the following points can be noted. Generally, the base shear does not depend on beam strength. The average lateral drifts of the frames with weak and very weak beams are $47 \%$ and $85 \%$ higher than those of the strong beam case. The buckling of the compression brace mostly occurs in the first story. Thus, most of the lateral drift is concentrated on the first story. In average, drift ratio of the first story is $1.6 \%, 2.2 \%$, and $3.1 \%$ for strong, weak, and very weak beams, respectively. This increase in the drift ratio of the first story clearly demonstrates how inadequate beam can provoke formation of soft story. In addition, mid-span vertical deformations of the weak and very weak beams in the first story are 3.6 and 6.8 times that of the strong beam, respectively, which explains the higher drift ratio in the first story.

Following AISC 341-10 provisions as presented in Table 3, the predicted unbalanced shear and axial forces in the strong beam were 648 and $1528 \mathrm{kN}$, respectively. This calculation was carried out by ignoring the depth of frame members and gusset plate dimensions. Thus, full-span length of $6 \mathrm{~m}$ and simple beam-column connection were considered. The average unbalanced shear and axial forces of the first-story strong beam were 872 and $1865 \mathrm{kN}$, respectively. This difference can mainly be attributed to strain hardening of steel in the tension brace. For instance, in the first story of the braced frame with strong beam under FF4 record, maximum tensile force of elongated brace reached $1623 \mathrm{kN}$ when compression force of buckled brace was $396 \mathrm{kN}$. Consequently, unbalanced shear force in the beam was, (1623-396) $\sin 46=902 \mathrm{kN}$ which reasonably matched the reported value in Table 6 . Furthermore, rigid behavior of the beam-column connection in the presence of corner gusset plates differed from the regular pinned connection behavior assumption.

The shear in the beam resulting from unbalanced force was proportional to flexural strength, but the axial forces in all cases were relatively similar. It should be noted that compression brace buckling mostly occurs in the first story; therefore, shear force in the firststory beam is much more than that in the second-story beam.

\subsection{Cyclic pushover analysis of two-story $X$ braced frame}

To examine the influence of bracing configuration on lateral behavior of a braced frame with very weak beam, nonlinear cyclic pushover analysis was employed and the results were compared with those for the 
Table 6. Peak nonlinear dynamic response of two-story braced frame subjected to seven scaled records.

\begin{tabular}{|c|c|c|c|c|c|c|c|c|c|c|c|c|}
\hline \multirow{3}{*}{ 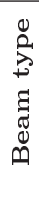 } & \multirow{3}{*}{ 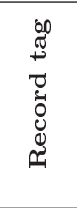 } & \multirow{3}{*}{ 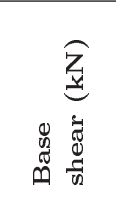 } & \multirow{3}{*}{ 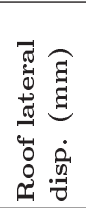 } & \multirow{2}{*}{\multicolumn{3}{|c|}{ Drift ratio (\%) }} & \multirow{2}{*}{\multicolumn{2}{|c|}{$\begin{array}{c}\text { Beam vertical } \\
\text { deflection }(\mathrm{mm})\end{array}$}} & \multicolumn{4}{|c|}{$\begin{array}{c}\text { Beam unbalance } \\
\text { force }(\mathrm{kN})\end{array}$} \\
\hline & & & & & & & & & \multicolumn{2}{|c|}{ Shear } & \multicolumn{2}{|c|}{ Axial } \\
\hline & & & & $\begin{array}{l}\text { 1st } \\
\text { story }\end{array}$ & $\begin{array}{l}\text { 2nd } \\
\text { story }\end{array}$ & Frame & $\begin{array}{c}\text { 1st } \\
\text { story }\end{array}$ & $\begin{array}{l}2 \text { nd } \\
\text { story }\end{array}$ & $\begin{array}{l}\text { 1st } \\
\text { story }\end{array}$ & $\begin{array}{l}\text { 2nd } \\
\text { story }\end{array}$ & $\begin{array}{l}\text { 1st } \\
\text { story }\end{array}$ & $\begin{array}{l}\text { 2nd } \\
\text { story }\end{array}$ \\
\hline \multirow{9}{*}{ 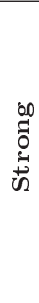 } & NF-1 & 2,347 & 64.4 & 1.665 & 0.364 & 0.977 & 16.4 & 2.1 & 967 & 98 & 1,954 & 1,785 \\
\hline & $\mathrm{NF}-2$ & 1,927 & 17.1 & 0.355 & 0.201 & 0.260 & 4.9 & 0.2 & 401 & 29 & 1,739 & 1,245 \\
\hline & FF-3 & 2,336 & 84.4 & 2.230 & 0.339 & 1.280 & 16.7 & 3.7 & 993 & 94 & 1,895 & 1,612 \\
\hline & $\mathrm{FF}-4$ & 2,273 & 54.3 & 1.441 & 0.298 & 0.823 & 15.5 & 1.6 & 905 & 77 & 1,833 & 1,544 \\
\hline & FF-5 & 2,434 & 83.3 & 2.226 & 0.344 & 1.263 & 22.0 & 5.6 & 993 & 95 & 1,944 & 1,650 \\
\hline & FF-6 & 2,317 & 69.6 & 1.825 & 0.314 & 1.055 & 17.5 & 2.5 & 998 & 91 & 1,931 & 1,701 \\
\hline & FF-7 & 2,266 & 51.4 & 1.361 & 0.324 & 0.779 & 13.6 & 1.9 & 851 & 87 & 1,759 & 1,788 \\
\hline & Avg. & $2,271.4$ & 60.6 & 1.586 & 0.312 & 0.920 & 15.2 & 2.5 & 872.5 & 81.5 & $1,865.0$ & $1,617.7$ \\
\hline & S.D. & 149.8 & 21.4 & 0.595 & 0.050 & 0.324 & 4.8 & 1.6 & 199.1 & 22.2 & 82.4 & 173.0 \\
\hline \multirow{9}{*}{$\sum_{3}^{\stackrel{y}{\tilde{d}}}$} & NF-1 & 2,133 & 93.9 & 2.313 & 0.646 & 1.424 & 58.2 & 12.2 & 703 & 266 & 1,854 & 1,646 \\
\hline & NF-2 & 1,781 & 22.6 & 0.500 & 0.210 & 0.342 & 11.0 & 0.4 & 339 & 22 & 1,625 & 1,135 \\
\hline & FF-3 & 2,103 & 121.2 & 2.471 & 1.565 & 1.838 & 59.3 & 39.4 & 698 & 452 & 1,783 & 1,582 \\
\hline & FF-4 & 1,897 & 58.2 & 1.544 & 0.295 & 0.882 & 40.0 & 0.8 & 605 & 51 & 1,704 & 1,501 \\
\hline & FF-5 & 2,046 & 97.8 & 2.613 & 0.362 & 1.483 & 62.3 & 3.9 & 635 & 54 & 1,721 & 1,584 \\
\hline & FF-6 & 2,112 & 155.5 & 4.231 & 0.494 & 2.358 & 108.5 & 3.9 & 794 & 63 & 1,670 & 1,530 \\
\hline & $\mathrm{FF}-7$ & 1,945 & 75.1 & 1.955 & 0.385 & 1.139 & 48.0 & 1.2 & 673 & 55 & 1,716 & 1,550 \\
\hline & Avg. & $2,002.4$ & 89.2 & 2.232 & 0.565 & 1.352 & 55.3 & 8.8 & 635.1 & 137.5 & $1,724.6$ & $1,504.0$ \\
\hline & S.D. & 122.2 & 39.8 & 1.052 & 0.428 & 0.604 & 27.1 & 13.0 & 133.2 & 148.9 & 69.3 & 156.7 \\
\hline \multirow{9}{*}{$\begin{array}{l}\breve{y} \\
0 \\
0 \\
3 \\
\text { ते } \\
0 \\
0\end{array}$} & NF-1 & 2,030 & 113.1 & 3.111 & 0.357 & 1.715 & 97.2 & 7.1 & 330 & 43 & 1,793 & 1,506 \\
\hline & NF-2 & 1,866 & 22.2 & 0.531 & 0.200 & 0.337 & 15.9 & 0.2 & 162 & 6 & 1,673 & 996 \\
\hline & FF-3 & 2,032 & 165.6 & 4.695 & 0.327 & 2.511 & 153.6 & 4.6 & 317 & 10 & 1,710 & 1,295 \\
\hline & $\mathrm{FF}-4$ & 1,754 & 66.9 & 1.794 & 0.248 & 1.015 & 67.7 & 2.1 & 261 & 11 & 1,601 & 1,173 \\
\hline & FF-5 & 1,895 & 135.2 & 3.766 & 0.339 & 2.050 & 124.9 & 4.0 & 308 & 12 & 1,713 & 1,278 \\
\hline & FF-6 & 2,004 & 190.3 & 5.452 & 0.358 & 2.886 & 175.4 & 4.9 & 341 & 14 & 1,819 & 1,309 \\
\hline & FF-7 & 2,074 & 91.5 & 2.634 & 0.333 & 1.388 & 90.1 & 3.1 & 296 & 12 & 1,861 & 1,370 \\
\hline & Avg. & $1,950.7$ & 112.1 & 3.140 & 0.309 & 1.700 & 103.5 & 3.7 & 287.9 & 15.5 & $1,738.6$ & $1,275.4$ \\
\hline & S.D. & 106.8 & 53.5 & 1.560 & 0.056 & 0.812 & 49.7 & 2.1 & 56.7 & 11.4 & 83.8 & 147.3 \\
\hline
\end{tabular}

chevron CBF cases. Two-Story X Braced Frame (TSXBF) configuration, in which $\mathrm{V}$ - and inverted-V braces in alternate stories create an X-configuration over two stories, has become one of the most commonly used SCBFs in areas with high seismicity. Employing and studying TSXBF has drawn considerable attention [29-31], because the brace-intersected beams in TSXBFs are much lighter than other CBF configurations such as chevron braced frames. According to AISC Seismic Provisions, the brace-intersected beams in TSXBFs can be designed considering the first-mode lateral loading pattern, which reduces the vertical unbalanced loads acting on the brace-intersected girders of TSXBFs, especially if braces have similar cross sections. Following the seismic provisions, TSXBF with very weak beam (IPE270) can adequately carry lateral load effect.

The beam, column, and brace sections of TSXBF and chevron CBF with very weak beams are similar as listed in Table 2. Figure 23 presents deformed shapes of TSCBF, in which lateral drift mainly occurs in the second and third stories. At maximum frame drift of $1.4 \%$, drifts of the first, second, third, and fourth stories were $0.7 \%, 2.3 \%, 2.1 \%$, and $0.4 \%$, respectively.

Cyclic pushover responses of TSXBF and chevron

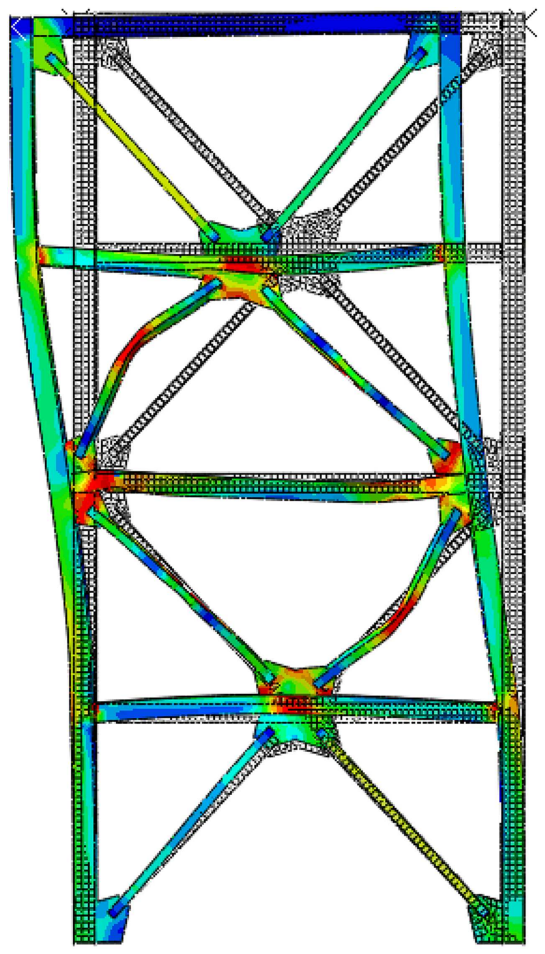

Figure 23. Deformed shape of four-story TSXBF with scale factor of 5 . 


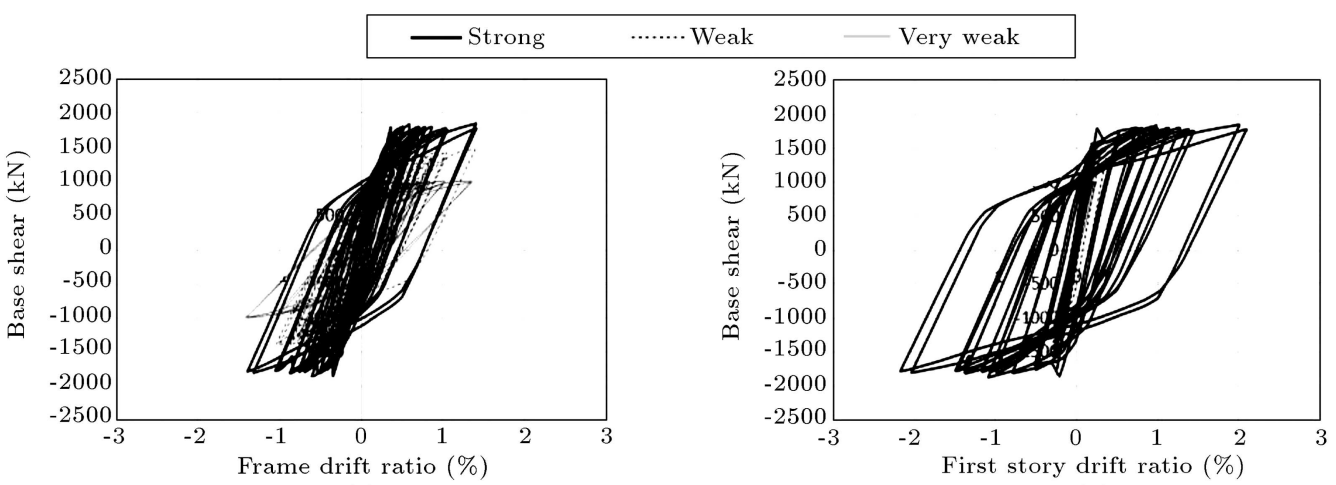

(a)

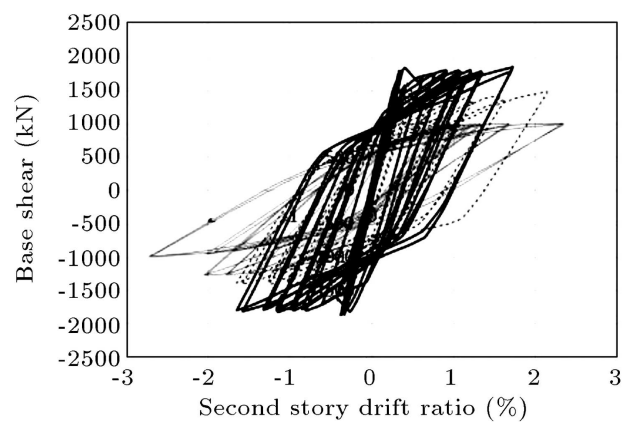

(b)

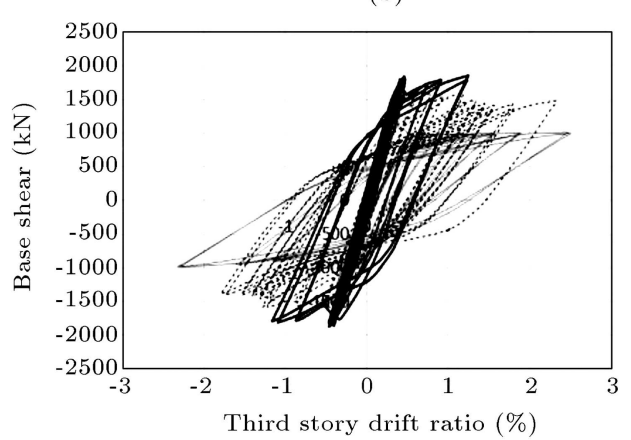

(c)

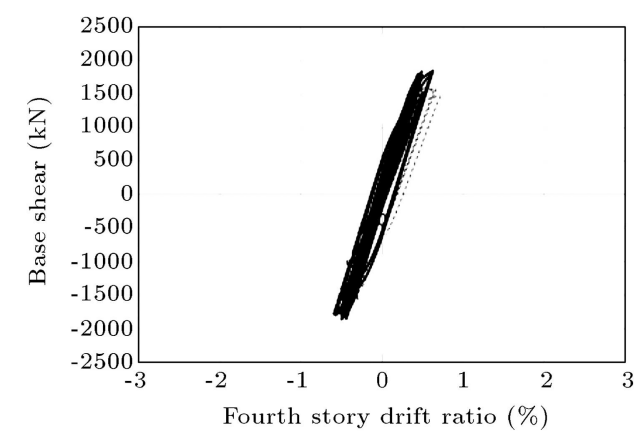

(d)

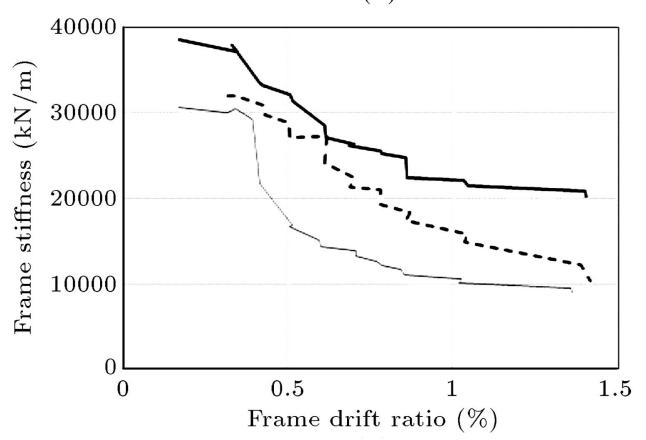

(e)

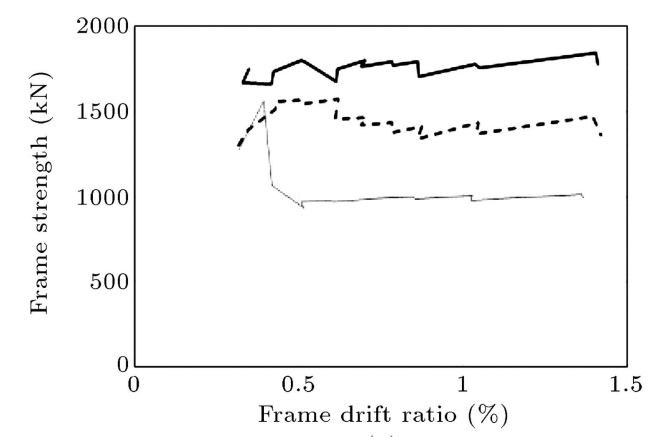

(g)

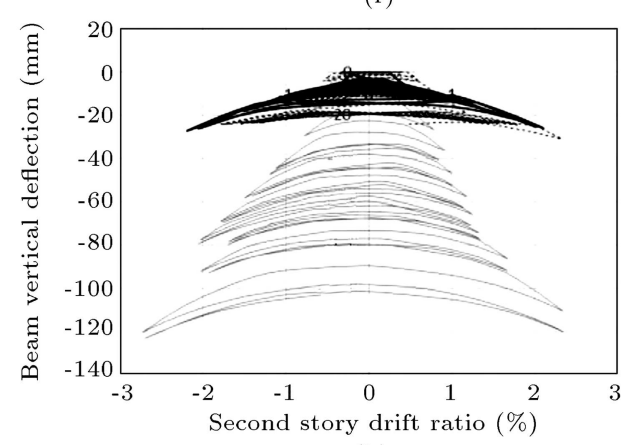

(h)

Figure 24. Comparing results of four-story TSXBF and Chevron CBF in cyclic pushover analysis: (a) Shear drift of frame, (b) shear drift of the first story, (c) shear drift of the second story, (d) shear drift of the third story, (e) shear drift of the fourth story, (f) lateral stiffness drift of frame, $(\mathrm{g})$ lateral strength drift of frame, and (h) vertical deformation drift of the third-story beam.

CBF are compared in Figure 24. The maximum vertical deformation of the beam in TSXBF is $30 \mathrm{~mm}$ and the maximum beam deflections are respectively 26, 70, and $120 \mathrm{~mm}$ for chevron braces with strong, weak, and very weak beams. For TSXBF, the av- erage strength of the frame decreases by $17 \%$ with respect to the chevron $\mathrm{CBF}$ with strong beam. The initial relative stiffness of TSXBF in comparison with chevron braced frame with strong beam is $86 \%$, but the average lateral stiffness of TSXBF is $24 \%$ lower 
than that of CBF with strong beam. Decreasing beam strength results in considerable increase in vertical deformation of beam (Figure 14(b) and (c)). The twostory $\mathrm{X}$ configuration prevents lateral strength drop when lateral drift increases, as can be observed in the chevron CBF with weak or very weak beam. It is apparent that two-story $\mathrm{X}$ configuration retrieves the adverse effect of beam weakness to some extent, but comparing lateral strength and stiffness reveals that the chevron braced frame with appropriate beam has superior seismic behavior.

\section{Conclusions}

Results of numerical simulation of two- and fourstory chevron CBFs with strong, weak, and very weak braced-intersected beams through nonlinear cyclic pushover analysis and nonlinear response history analysis were presented. The numerical simulation performed by means of ABAQUS software was able to capture nonlinear steel material, buckling, and postbuckling behaviors of compression braces; presence and details of gusset plates; and large deformation effects. Adequacy of numerical simulation was verified by comparing the results of the model with those of an experimental study of two-story chevron braced frame with weak beam. Seismic responses were discussed in terms of lateral stiffness and lateral strength of frame, vertical deformation and unbalanced force in beam, and inter-story drift ratios. Seismic behavior of two-story X braced frame in mitigating adverse effect of weak beam in chevron braced frame was also discussed. Major findings of this study were as follows:

1. The beam in chevron braced frame underwent large unbalanced shear force proportional to beam flexural strength. In the strong beam case, small vertical deformation occurred at beam mid-span, tension brace could yield, lateral force was mainly carried through truss action of braced frame, and relatively uniform height-wise lateral deformation was observed;

2. When flexural strength of the beam was not sufficient, e.g., in weak and very weak beam cases, midspan vertical deformation of the beam was high, tension brace remained almost elastic, braced frame supported lateral force by truss action and frame action, and the yielding beam concentrated lateral drift on a soft story;

3. Employing two-story $\mathrm{X}$ braced frame configuration could not completely retrieve the adverse effect of weak beam in chevron CBF. Chevron CBF with strong beam had higher lateral stiffness and strength than 'TSXBF' with very weak beam;

4. The necessity of providing the required strength for the beam of the chevron braced system was clearly demonstrated. The chevron braced frame with strong beam had superior seismic behavior.

\section{References}

1. ANSI, AISC "Seismic provisions for structural steel buildings (ANSI/AISC 341-10)", American Institute of Steel Construction, Chicago (IL), US (2010).

2. INBC, "INBC 10-12", Design and Construction of Steel Buildings, Tehran, Iran: Iran National Building Code (2012).

3. Robert, N. and Tremblay, R. "Seismic design and behaviour of chevron steel braced frames", In Proc. 12th World Conf. on Earthquake Engrg., Auckland, NZ (2000).

4. Rai, D.C. and Goel, S.C. "Seismic evaluation and upgrading of chevron braced frames", Journal of Constructional Steel Research, 59(8), pp. 971-994 (2003).

5. Uriz, P. and Mahin, S.A. "Seismic performance assessment of concentrically braced steel frames", In Proceedings of the 13th World Conference on Earthquake Engineering, Vancouver, Canada (2004).

6. Kim, J. and Choi, H. "Response modification factors of chevron-braced frames", Engineering Structures, 27(2), pp. 285-300 (2005).

7. Marino, E.M. and Nakashima, M. "Seismic performance and new design procedure for chevron-braced frames", Earthquake Engineering \& Structural Dynamics, 35(4), pp. 433-452 (2006).

8. Dicleli, M. and Mehta, A. "Effect of near-fault ground motion and damper characteristics on the seismic performance of chevron braced steel frames", Earthquake Engineering \& Structural Dynamics, 36(7), pp. 927948 (2007).

9. Dicleli, M. and Mehta, A. "Simulation of inelastic cyclic buckling behavior of steel box sections", Computers \& Structures, 85(7), pp. 446-457 (2007).

10. Hines, E.M., Appel, M.E., and Cheever, P.J. "Collapse performance of low-ductility chevron braced steel frames in moderate seismic regions", Engineering Journal, American Institute of Steel Construction, 46(3), pp. 149-180 (2009).

11. Giugliano, M.T., Longo, A., Montuori, R., and Piluso, V. "Seismic reliability of traditional and innovative concentrically braced frames", Earthquake Engineering \& Structural Dynamics, 40(13), pp. 1455-1474 (2011).

12. Tong, G.S., Luo, G.F., and Zhang, L. "Lateral resistance of chevron-braced frames with weak beams", Engineering Mechanics, 28(8), pp. 89-98 (2011).

13. Zhang, L., Luo, G.F., and Tong, G.S. "Behaviour of chevron bracing system of weak beam in resisting lateral force", Engineering Mechanics, 31(1), pp. 104112 (2014). 
14. Hsiao, P.C., Lehman, D.E., and Roeder, C.W. "Improved analytical model for special concentrically braced frames", Journal of Constructional Steel Research, 73, pp. 80-94 (2012).

15. Hsiao, P.C. Seismic Performance Evaluation of Concentrically Braced Frames, PhD Dissertation, University of Washington (2012).

16. Lai, J.W. and Mahin, S.A. "Strongback system: A way to reduce damage concentration in steel-braced frames", Journal of Structural Engineering, 141(9), p. 04014223 (2014).

17. D'Aniello, M., Costanzo, S., and Landolfo, R. "The influence of beam stiffness on seismic response of chevron concentric bracings", Journal of Constructional Steel Research, 112, pp. 305-324 (2015).

18. Asghari, A. and Azimi, B. "Evaluation of sensitivity of CBFs for types of bracing and story numbers", Scientia Iranica, Transaction A, Civil Engineering, 24(1), p. 40 (2017).

19. Kazemzadeh Azad, S., Topkaya, C., and Astaneh-Asl, A. "Seismic behavior of concentrically braced frames designed to AISC341 and EC8 provisions", Journal of Constructional Steel Research, 133, pp. 383-404 (2017).

20. Fukuta, T., Nishiyama, I., Yamanouchi, H. and Kato, B. "Seismic performance of steel frames with inverted V braces", Journal of Structural Engineering, 115(8), pp. 2016-2028 (1989).

21. Bubela, R.K., Ventura, C.E., and Prion, H.G. "Cyclic testing of steel chevron braces with vertically slotted beam connection", IJASE, 2(1), p. 50 (2010).

22. Okazaki, T., Lignos, D.G., Hikino, T., and Kajiwara, K. "Dynamic response of a chevron concentrically braced frame", Journal of Structural Engineering, 139(4), pp. 515-525 (2012).

23. Sen, A.D., Sloat, D., Pan, L., Roeder, C.W., Lehman, D.E., and Berman, J.W. "Evaluation of the seismic performance of two-story concentrically braced frame with weak beams", In Proceedings of 5th International Conference on Advances in Experimental Structural Engineering, Taipei, Taiwan (2013).

24. Sen, A.D., Pan, L., Sloat, D., Roeder, C.W., Lehman, D.E., Berman, J.W., Tsai, K.C., Li, C.H., and Wu, A.C. "Numerical and experimental assessment of chevron braced frames with weak beams", In Proceedings 10th US National Conference of Earthquake Engineering, Anchorage, Alaska, US (2014).

25. Sen, A.D., Roeder, C.W., Berman, J.W., Lehman, D.E., Li, C.H., Wu, A.C., and Tsai, K.C. "Experimental investigation of chevron concentrically braced frames with yielding beams", Journal of Structural Engineering, 142(12), p. 04016123 (2016).
26. ANSI, AISC. "Specification for structural steel buildings (ANSI/AISC 360-10)", American Institute of Steel Construction, Chicago (IL), US (2010).

27. ASCE, Minimum Design Loads for Buildings and Other Structures (ASCE 7-10), American Society of Civil Engineers, Reston (VA), US (2010).

28. www.iranhazard.mporg.ir/

29. Shen, J., Wen, R., Akbas, B., Doran, B., and Uckan, E. "Seismic demand on brace-intersected beams in twostory $X$-braced frames", Engineering Structures, 76, pp. 295-312 (2014).

30. Wen, R., Seker, O., Akbas, B., and Shen, J. "Designs of special concentrically braced frame using AISC 34105 and AISC 341-10", Practice Periodical on Structural Design and Construction, 21(1), p. 04015011 (2015).

31. Shen, J., Wen, R., and Akbas, B. "Mechanisms in two-story X-braced frames", Journal of Constructional Steel Research, 106, pp. 258-277 (2015).

\section{Biographies}

Seyed Mehdi Dehghan is an Associate Professor in Civil and Environmental Engineering Department at Shiraz University of Technology. He received his BSc and MSc degrees from Shiraz University Shiraz, Iran. Also, he received his $\mathrm{PhD}$ degree in Structural Engineering from Tohoku University, Japan, in 2008. His research interests include seismic behavior of steel, RC, and masonry structures; passive control of structures; and seismic isolation.

Mohammad Amir Najafgholipour is an Associate Professor in Civil and Environmental Engineering Department at Shiraz University of Technology Shiraz, Iran. He received his $\mathrm{BSc}, \mathrm{MSc}$, and $\mathrm{PhD}$ degrees from Shiraz University in 2004, 2007, and 2012, respectively. He was on a sabbatical at Minho University, Portugal, in 2011. His main areas of research interest are seismic performance evaluation and retrofitting of existing buildings, and experimental and numerical studies of masonry and RC structures. He now serves as a committee member of the Iranian National Building Code for Design and Construction of Masonry Buildings.

Hossein Hooshangi is currently a $\mathrm{PhD}$ candidate at Shiraz University of Technology, Shiraz, Iran. He received his MSc degree from the same university in 2015. He is interested in seismic behavior and numerical simulation of different steel structural systems. 